\title{
Glucokinase and candidate genes for Type 2 (non-insulin-dependent) diabetes mellitus
}

\author{
P.J. Randle \\ Nuffield Department of Clinical Biochemistry, University of Oxford, John Radcliffe Hospital, Oxford, UK
}

It has been known since 1962 that glucokinase (GK) is an important determinant of rates of hepatic glucose uptake, and knowledge of its likely role as glucoreceptor in glucose-induced insulin release from islet beta cells dates from 1963/1964. (The term glucoreceptor is preferred to glucose sensor and has been used since the 1960s. Sensors transmit information to or through the nervous system whereas receptors transduce external concentration into a cellular response; the latter is more appropriate for the beta-cell response to glucose). Recently important new dimensions have been added to the metabolic role and significance of glucokinase. This work together with the recent discovery of mutations in the GK gene in families with the MODY variant of Type 2 (non-insulin-dependent) diabetes (maturity onset diabetes of the young) has prompted this review.

\section{Historical and general}

\section{Discovery of liver glucokinase}

Intracellular metabolism of glucose in animal tissues is initiated by phosphorylation of the sugar to glucose 6-phosphate (Fig. 1). In all animal tissues except liver and islet beta cells this reaction is catalysed by hexokinase (HK) isoenzymes I, II or III. For these HKs the $\mathrm{K}_{\mathrm{m}}$ for glucose is in the range 0.01 to $0.1 \mathrm{mmol} / 1$ and is less than $2 \%$ of the fasting blood glucose concentration. In these tissues dependence of rates of glucose metabolism on extracellular glucose concentration is conferred by the activity of plasma membrane glucose transporters (GLUT 1, 3 and 4, depending on tissue [1]).

The studies of Cahill et al. [2,3] first showed in 1958 that hepatocytes are freely permeable to glucose and that the rate of intracellular phosphorylation is therefore dependent on glucose concentration over the physiological range (4-9 mmol/1). This pointed to the existence of an HK with a much higher $K_{m}$ for glucose than the values of 0.01-0.1 $\mathrm{mmol} / \mathrm{l}$ for HKs known at the time. This enzyme activity (HK IV or GK) was subsequently identified in liver homogenates by Weinhouse and co-workers [4] and the enzyme purified by Sols and colleagues $[5,6]$ in $1963-$ 1966. The name glucokinase was adopted, partly in deference to Carl Cori, and partly to distinguish its unique properties amongst $\mathrm{HKs}$ viz lower $\mathrm{M}_{\mathrm{r}}$ (molecular weight), higher $\mathrm{K}_{\mathrm{m}}$ for glucose $(12 \mathrm{mmol} / \mathrm{l})$, sigmoid glucose concentration-reaction velocity relationship (Hill coefficient 1.6), and absence of inhibition by the reaction product glucose 6-phosphate. GK is not specific for glucose; values for $\mathrm{K}_{\mathrm{m}}$ (in $\mathrm{mmol} / \mathrm{l}$ ) and relative $\mathrm{V}_{\max }$ are glucose $(12,100)$ mannose $(33,80) 2$-deoxyglucose $(55,28)$ fructose $(>800$, 8) $[6]$

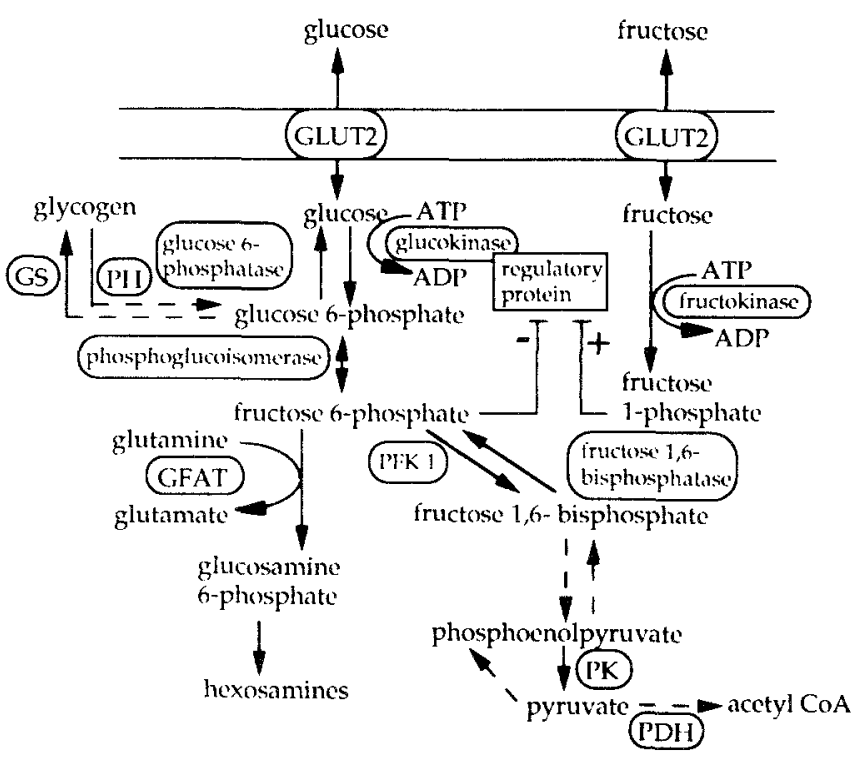

Fig. 1. Pathways of glucose metabolism in liver and pancreatic islet beta cells of significance to hepatic glucose utilisation and insulin release by beta cells. Fructose 1,6-bisphosphatase activity has not been detected in beta cells. GLUT 2, glucose transporter 2 (evidence that it transports fructose is given by Gould et al. [89]); GFAT, Glutamine: fructose 6-phosphate amidotransferase; PFK 1, phosphofructo-1-kinase; $\mathrm{PK}$, pyruvate kinase; $\mathrm{PDH}$, pyruvate dehydrogenase complex; GS, glycogen synthase; $\mathrm{PH}$, phosphorylase 


\section{Discovery of pancreatic islet glucokinase}

Studies by Grodsky and co-workers [7] and by Coore and Randle [8] in 1962-1964 first showed that only sugars which are substrates for HKs and for glycolysis elicit insulin release thus suggesting a link between their metabolism and insulin release. These studies also showed that the concentration of glucose required for half-maximum stimulation of insulin release was of the order of $10 \mathrm{mmol} / \mathrm{l}$. Coore and Randle [8] concluded in 1964, on the basis of their findings, that islet beta cells are freely permeable to glucose and contain GK, and that "phosphorylation of glucose in the beta cell may control glucose metabolism and the secretion of insulin" [9]. The findings were 1) D-mannoheptulose inhibits insulin release induced by glucose and mannose but not that induced by tolbutamide $[8,10] 2) \mathrm{D}$-mannoheptulose inhibits rat or rabbit liver GK $\left(\mathrm{K}_{\mathrm{i}} 1 \mathrm{mmol} / \mathrm{l}\right)$ and HKs $[6,11]$ and glucose uptake by rat liver [11]3) phloridzin, D-galactose and 3-Omethyl-D-glucose (inhibitors of glucose-transport) do not inhibit glucose-induced insulin release $[7,8]$ whereas Dglucosamine which inhibits $\mathrm{GK}\left(\mathrm{K}_{\mathrm{i}} 0.5 \mathrm{mmol} / \mathrm{l}\right)$ [6] is inhibitory [8]. In 1968 Matschinsky and Ellerman [12] confirmed this conclusion by direct analysis of islet glucose, and the presence of HKs in islet extracts with low and high $\mathrm{K}_{\mathrm{m}}$ for glucose was shown by them and by Ashcroft and Randle [12-15]. The definitive evidence for the presence of GK protein in pancreatic islets was obtained by immuno-blotting and by the detection of mRNA (Iynedjian and co-workers $[16,17])$; by immunocytochemical localisation to islet beta cells [18]; and by isolation and sequence analysis of full length cDNA by Magnuson, Permutt and colleagues [18-20] (this latter method has revealed structural differences between liver and islet GKs which are discussed later).

\section{Metabolism of sugars and insulin release}

Two glucoreceptor models were proposed in 1968 for the effects of glucose and related sugars on insulin release. The regulator site model envisaged glucose acting directly by an allosteric mechanism (i.e. at a regulator site) to switch a cell signalling system whereas the substrate site model envisaged glucose acting via the substrate site of GK and a metabolic pathway [21]. There was a period (1971-1973) when the validity of the substrate site model and the role of GK was seriously challenged in papers from Matschinsky and colleagues purporting to show stimulation of insulin secretion by a non-metabolisable sugar [22] and dissociation of metabolic and secretory events [23] but this was not substantiated. Evidence is now overwhelmingly in favour of the substrate site model. Exhaustive studies have revealed no exception to the rule that only sugars that are metabolised elicit insulin secretion. Moreover studies from the laboratories of Hellman, Hedeskov and Ashcroft show that insulin release is elicited by dihydroxyacetone, glyceraldehyde, inosine, and $\mathrm{N}$-acetylglucosamine (NAG), molecules either structurally unrelated to glucose, or which enter the glycolytic pathway by independent routes bypassing GK or HK [2426]. In isolated pancreatic islets the relationships between glucose concentration and rates of insulin release, (pro)insulin biosynthesis, and a number of different parameters of rates of glucose metabolism are closely similar; inhibitors of glucose phosphorylation (mannoheptulose and glucosamine) inhibit both insulin release and glucose metabolism (reviewed in [24, 27]).

Particularly compelling evidence has come from a comparison of glucose and NAG which share a common transporter but are phosphorylated by different kinases. Islet metabolism of each of these sugars was found to be selectively blocked by specific inhibitors (transport inhibitors for NAG; GK inhibitors for glucose). The same pattern of inhibitor specificity was shown to apply to insulin release (reviewed in [24]). Two residual potential anomalies are the potentiation of glucose-induced release by fructose and the failure of NAG (a GK inhibitor) to inhibit glucose-induced release [28]. The fructose effect is explicable through fructose 1-phosphate activation of GK (see later section). Lack of inhibition by NAG ( $\mathrm{K}_{\mathrm{i}}$ for $\mathrm{GK}$ $40 \mathrm{mmol} / \mathrm{l}[6]$ ) is explicable by low transport rates, rapid intracellular removal by NAG kinase and NAG stimulation of insulin release [24,29].

Finally there is an hypothesis to explain the mechanism whereby glucose metabolism induces insulin release: namely that enhanced glucose metabolism leads through increased beta cell [ATP]/[ADP] (concentration ratio) to closure of ATP-dependent $\mathrm{K}^{+}$channels, membrane depolarisation and opening of voltage-dependent $\mathrm{Ca}^{2+}$ channels [30]. The ensuing increase in beta-cell $\mathrm{Ca}^{2+}$ provokes insulin release [30], and is expected to sustain elevation of [ATP]/[ADP] through actions of $\mathrm{Ca}^{2+}$ on mitochondrial dehydrogenases and respiratory chain phosphorylation [31]. It is important to appreciate that glucose-induced increases in glucose oxidation in beta cells are accompanied by increased $\mathrm{O}_{2}$ consumption as first demonstrated by Hellerström [32]. The implication is that increased oxidations are driven by ATP turnover, occasioned by increased secretion and synthesis of insulin; and that glucose is oxidised because of activation of the pyruvate dehydrogenase complex effected by $\mathrm{Ca}^{2+}$ and inhibition of fatty acid oxidation effected by malonyl CoA.

\section{Glucose 6-phosphatase; glucose transporter 2}

Consideration of the functional role of GK requires reference to glucose 6-phosphatase and glucose transporter 2 (GLUT 2) (Fig. 1). Glucose 6-phosphatase reverses the GK reaction and thus net glucose phosphorylation is the difference between the two opposing reactions. In liver, glucose 6-phosphatase is a membrane system composed of an intralumenal phosphatase and transporters for glucose 6-phosphate, glucose and $\mathrm{P}_{\mathrm{i}}[33]$, and catalyses the terminal reaction in hepatic glucose production. It is also present in islets at high activity [14, 33, 34], has been detected by both bio- and immuno-assays, and histochemical evidence reviewed by Waddell and Burchall [33] shows beta-cell location. Islet glucose 6-phosphatase is inhibited by glucose at physiological concentrations $[14,34]$. This is of considerable potential importance. It is expected to enhance the sigmoid relationship between glucose concen- 


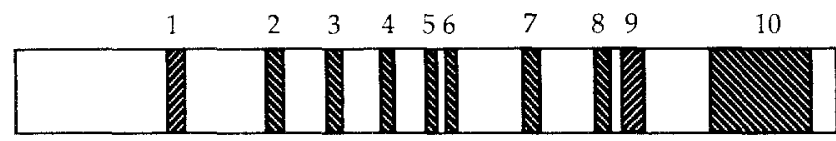

0

5 kilobases

10

15

Fig.2. Structure of the rat glucokinase gene based on data given by Tanizawa et al. [38]. Exons 1-10 are shown by shaded areas. Subsequent studies indicated an alternative exon 1 upstream from the one shown [18]. The human gene is organised in similar fashion except for a third alternative exon 1 downstream from that shown [39] (i.e. rat has exons $1 \mathrm{a}, 1 \mathrm{~b}$; man has exons $1 \mathrm{a}, 1 \mathrm{~b}, 1 \mathrm{c}$ )

tration and glucose phosphorylation and hence of insulin release, but it is often ignored by reviewers.

GLUT 2 is present both in liver and islets [35]. In liver its high $\mathrm{K}_{\mathrm{m}}$ presumably allows for sensitive switching between glucose uptake and release. In the islet beta cell the high $\mathrm{K}_{\mathrm{m}}$ of GLUT 2 presumably facilitates rapid re-equilibration of intra-islet glucose concentration when blood glucose concentration is altered. GLUT 2 protein was unchanged by starvation or streptozotocin diabetes whereas mRNA was decreased $\sim 50 \%$ by starvation and normalised by refeeding [36].

\section{Chemistry, genetics and regulation of glucokinase}

\section{Structural studies}

Only one GK gene is detected in man and rat (chromosome 7 band $p 13$ in man [37]). Isoenzymes are formed by differential splicing of GK mRNA [19,38]. Amino acid sequences (liver and islet beta-cell GKs) in both species have been deduced mainly from nucleotide sequences of full length cDNA $[19,20,37-41]$.

Rat liver GKs contain 465 amino acids $[39,40]$ and the two human liver GK isoenzymes (464 and 466 amino acids) show 97 and $98 \%$ homology with the rat liver enzyme [38]. The two isoenzymes differ from each other in the sequence of $16 \mathrm{~N}$-terminal amino acids as a result of alternative splicing of a 123 base pair cassette exon between liver exons 1 and $2[38,41]$.

In both rat $[17,19]$ and man $[20,37]$ islet beta-cell GKmRNA is longer than its liver counterpart and there is evidence for more than one isoenzyme (alternative splicing) [19] . Comparison of islet and liver cDNAs predicts N-terminal sequence differences in 15 amino acids. In the rat cDNA sequencing studies also show alternative promoters in islet beta cells and liver separated by at least $12 \mathrm{ki}$ lobases $(\mathrm{kb})$ in the gene [19]. There is evidence for similar alternative promoters in human liver and islet beta cells $[20,41]$. The use of different promoters in the two cell types predicts possible tissue specific regulatory functions (see next section).

Amino acid sequences of GKs show 53 and $33 \%$ homology with the C-terminal domains of rat brain HK I and yeast $\mathrm{HK}$ and a high degree of structural conservation at the putative glucose- and ATP-binding domains [39]. The $\mathrm{M}_{\mathrm{r}}$ of HKs are approximately twice that of GKs; the glucose 6-phosphate inhibitory site which is absent in GK is in the $\mathrm{N}$-terminal domain of HKs [39].
The rat GK gene is $15.5 \mathrm{~kb}$ long and consists of 10 exons separated by 9 introns and predicts an mRNA of $2.357 \mathrm{~kb}$ excluding the poly A tail [40] (Fig. 2). Subsequent studies indicated an alternative exon $1 \mathrm{~b}$ upstream from the one shown (1a) [19]. The human gene has the same exon/intron organisation except for a third alternative exon $1 \mathrm{c}$ downstream from that shown [41] (i.e. rat has exons $1 \mathrm{a}$, $1 \mathrm{~b}$; man has exons $1 \mathrm{a}, 1 \mathrm{~b}, 1 \mathrm{c}$ ). Exons 2-10 encode the bulk of all GK mRNAs whereas exons $1 \mathrm{a}, 1 \mathrm{~b}$ and $1 \mathrm{c}$ encode parts of mRNAs for beta cell and two liver isoforms respectively [41].

\section{Regulation of cellular glucokinase concentration}

In rat liver, starvation, low carbohydrate diet and insulin deficiency decrease hepatic activity of GK, liver concentrations of GK protein and GKmRNA(s); and increase the concentration of glucose 6-phosphatase $[5,17,33,39$, 42-44]. The cDNAs for proteins of the glucose 6-phosphatase system have not yet been cloned. In cultured primary hepatocytes insulin effects a 20-30 fold increase in GK gene transcription; glucagon (cAMP) inhibits GK gene transcription and overrides the action of insulin; whereas ambient glucose concentration is without influence [4446]. Insulin may also play a major role in the postnatal induction of hepatic GK and GK mRNA in rats [44].

In rat islets starvation markedly decreases insulin secretory response to glucose; the effect is reversed by carbohydrate refeeding and reversal is blocked by actinomycin suggesting involvement of transcription [47]. The level of islet GK and GKmRNA remained constant during the fasting-refeeding cycle in [17]. This appeared to exclude effects on transcription of GK gene or translation of GKmRNA but the study of Tiedge and Lenzen [48] showed that starvation of rats decreased beta-cell GKmRNA by $53 \%$ (reversed by refeeding) and in the study of Malaisse et al. [49] starvation decreased islet GK activity by $\sim 50 \%$. Another possible contribution to effects of starvation is mediation by lipids. Intralipid in rats in vivo specifically inhibited subsequent glucose-induced insulin release in perfused pancreas but this required $48 \mathrm{~h}$ of infusion [50]. Fatty acyl CoA inhibits GK [51] but this is a rapid effect and perhaps unlikely to be responsible for the longer term intralipid effect.

In studies with rat islets in culture [52,53] glucose (20 or $30 \mathrm{mmol} / \mathrm{l}$ ) over 1 or 7 days as compared with glucose (1 or $3 \mathrm{mmol} / \mathrm{l}$ ) increased glucose-stimulated insulin release, glycolytic flux, GK activity, and GK protein [52] without increasing GKmRNA [53] whereas pyruvate dehydrogenase (PDH) activity and PDH $\alpha$-chain mRNA were increased nine-fold [53]. The response of GK to glucose appeared to involve activation of translation or inhibition of GK degradation or both. It has been concluded that insulin plays no part in the regulation of islet GK activity but current evidence does not wholly suffice for such a conclusion. Islets release insulin and released insulin might exert effects through secretory products of other islet cells.

Insulin appears to be the major positive effector of GK activity in liver whereas glucose concentration may fill this role in islet beta cells. Important secondary effects of glucose on the synthesis of other enzymes of glucose metabo- 
lism in islets seem likely to be involved also in the longer term regulation of glucose-induced insulin release.

\section{Glucokinase regulator protein}

In rat liver fructose increases uptake and phosphorylation of glucose and its conversion to glycogen, lactate, $\mathrm{CO}_{2}$ and amino acids (reviewed in [54]). The mechanism of the fructose effect has been investigated by Dr. E. Van Schaftingen and his colleagues. In an outstanding series of papers [54-59] they show that hepatic GK is inhibited by fructose 6-phosphate $\left(\mathrm{K}_{\mathrm{i}} 40 \mu \mathrm{mol} / \mathrm{l}[59]\right)$, that the effect of fructose 6-phosphate is reversed by fructose 1-phosphate $\left(\mathrm{K}_{0.5} 4.4 \mu \mathrm{mol} / \mathrm{l}\right)$, and that the effects of fructose phosphates require a specific regulatory protein [55]. In liver as in other tissues fructose 6-phosphate and glucose 6-phosphate are held in equilibrium by phosphoglucoisomerase. The inhibition of GK by fructose 6-phosphate is thus an indirect form of product inhibition. In liver fructose is phosphorylated to fructose 1-phosphate by fructokinase thus providing an explanation for the stimulation of glucose phosphorylation by fructose (Fig. 1).

The regulatory protein is present in pancreatic islets [60]. It exhibits the same properties as in liver and it regulates islet GK in a parallel fashion to liver GK. In rat and mouse islets fructose did not stimulate insulin release in the absence of glucose or at a concentration of glucose giving maximum release $(20 \mathrm{mmol} / \mathrm{l})$ but in the presence of a threshold concentration $(5.5 \mathrm{mmol} / \mathrm{l}$ of glucose) $20 \mathrm{mmol} / \mathrm{l}$ of fructose doubled the rate of insulin release [28]. Islets contain fructokinase [60] and fructose may potentiate glucose-induced insulin secretion through formation of fructose 1-phosphate, activation of GK, and enhanced metabolism of glucose. This is amenable to investigation. Intriguingly a recent study of the metabolic response to fructose in Type 2 diabetic subjects showed that doses of fructose which had little or no significant effect on plasma glucose concentration (15-35 g) increased plasma insulin and C-peptide [61].

The mechanism of action of the regulatory protein has been published [55,56], and a comprehensive list of inhibitory and stimulatory analogues acting through the regulatory protein has also been published [59].

\section{Regulatory interactions of the hexosamine biosynthesis pathway}

Fructose 6-phosphate, which in liver is formed via the GK and phosphoglucoisomerase reactions, is the starting point for the hexosamine biosynthesis pathway (Fig. 1). Reaction with glutamine, catalysed by glutamine: fructose 6-phosphate amidotransferase (GFAT) gives rise to glucosamine 6-phosphate and other hexosamine products. Evidence has recently been obtained in rat adipocytes that products of the hexosamine biosynthesis pathway may mediate longer term effects of insulin to induce $\mathbf{M}_{2}$ pyruvate kinase, to repress GFAT, and to desensitise the glucose transport system to insulin stimulation $[62,63]$. The evidence for involvement of the hexosamine pathway is based upon the simultaneous requirement for glucose, glutamine and insulin; and the ability of glucosamine to replace glutamine and glucose. Whether this pathway may have regulatory functions in other tissues has yet to be established. There is suggestive evidence for its involvement in liver in the longer term regulation of L-type pyruvate kinase and 6-phosphofructo-2-kinase/fructose 2,6-bisphosphatase [62]. The outcome of further studies in this pathway are awaited with interest.

\section{Glucokinase and candidate genes for Type $\mathbf{2}$ diabetes}

Type 2 diabetes is almost certainly heterogeneous from the genetic point of view. The high concordance rate amongst identical twins suggests a strong genetic component although environmental factors in pregnancy and infancy are another possibility [64]. The two major pathogenic components are a subnormal plasma insulin concentration, consistently demonstrable after controlling for obesity and blood glucose concentration [65]; and insulin resistance in respect of insulin-induced hypoglycaemia [66], muscle glycogen synthesis [67] and other aspects of glucose and fatty acid metabolism [68]. There is evidence that subnormal insulin secretory responses are specific for glucose as stimulus and not shared by tolbutamide, arginine, glucagon or $\beta$-adrenergic agonists (as reviewed by Robertson [69]). There is also evidence that the subnormal response to glucose is an adaptive response to chronic hyperglycaemia which may be partially reversed by tolbutamide, salicylate or phentolamine (reviewed in $[69,70])$. Matschinsky pointed out that such observations could have as their basis malfunction of GK in beta cells. This led him to advocate that the GK gene should be examined for mutations in Type 2 diabetes [71]. Population association studies of the GK gene locus between normoglycaemic and Type 2 diabetic American Blacks [72] and Mauritian Creoles [73] have been positive. Mutations have now been recorded in some families with MODY (Type 2 diabetes subtype presenting from the second decade with an autosomal dominant mode of inheritence) $[41,74-76])$ and in one pedigree thought to have classic Type 2 diabetes [77] but no other mutations have yet been identified in the common variety of the disease.

\section{Glucokinase gene mutations in Type 2 diabetes}

Linkage between the GK locus on chromosome $7 p$ and diabetes was first reported in 16 French families with MODY by Froguel et al. [76] and in a UK family by Hattersley et al. [74]. In the French study a nonsense mutation in exon 7 of the GK gene was identified [GAG (Glu) to TAG (amber termination codon)] [75] together with two further missense mutations in exon 7 (Thr-228 $\rightarrow$ Met and Gly-261 $\rightarrow$ Arg) that cosegregate with diabetes [41]. In the UK study a missense mutation in exon 8 was identified (Gly-299 $\rightarrow$ Arg) [77]. Molecular modelling studies suggest that mutation of Thr-228 may affect GK affinity for ATP and that Gly-261 mutation may affect glucose binding i.e. alteration of enzyme activity is predicted [41]. In both the UK [74] and French kindreds [78] fasting plasma insulin was unchanged whereas insulin secretory responses to glucose were reduced by $50-70 \%$ (plasma insulin and C-peptide measurements). First phase insulin respon- 
ses were decreased in the UK kindred [74, 79] but not in the French $[78,80]$. Insulin sensitivity was normal in the UK kindred. Further studies in French MODY kindreds have revealed additional abnormal conformers which cosegregated with diabetes in exons 4, 6, 7 and 8 and conformers in exon $1 \mathrm{a}$ and 9 that did not co-segregate with diabetes [81]. In exon 8, 3 missense mutations were identified [Glu-300 $\rightarrow$ Lys; Glu-300 $\rightarrow$ Gln; Leu-309 $\rightarrow$ Pro-309] [82].

There is clear evidence of genetic heterogeneity amongst MODY patients; linkage to glucokinase has been excluded in other pedigrees $[74,76]$ and other linkage has been reported [83]. Permutt and colleagues in a recent review including unpublished work [84] report a total of $16 \mathrm{GK}$ structural gene mutations in 18 of 32 French white MODY pedigrees. They estimate from the French studies that $55 \%$ of MODY pedigrees may be linked to GK; that MODY may possibly constitute $10-15 \%$ of familial Type 2 diabetes but a much smaller proportion of general or late-onset Type 2 diabetes. They estimate also that GK mutations will be rare $(<1 \%)$ in general Type 2 diabetes in white populations, but that estimates for other population groups are much less certain.

\section{Candidate genes for Type 2 diabetes}

Current knowledge of beta-cell glucose metabolism in relation to glucose-induced insulin secretion indicates clearly that there are many potential candidate genes for impaired insulin secretory response to glucose. The GK mutations recently described are believed to impair catalytic efficiency at substrate binding sites but there are many other potential sites. These include promoter regions (with potential for differential hepatic and beta-cell expression) and splicing sites; regulatory domains in GK e. g. the binding site for the fructose 6-/fructose 1-phosphate regulatory protein; and regulatory sites within the GK gene and its promoter region e.g. for possible induction by glucose. Likewise the fructose 6-/fructose-1-phosphate GK regulatory protein is an obvious candidate gene. Glucose transporters have received consideration with largely negative findings. GLUT 2 is of particular interest because of its functional role in beta cells. Negative findings have been reported in respect of linkage to Type 2 diabetes in American Blacks [85] and British MODY pedigrees [86] although a positive population association was reported in British Type 2 diabetic patients with a strong family history [87]. Mutations in components of islet glucose 6-phosphatase might be relevant to Type 2 diabetes if they result in enhanced activity (e.g. by mutations at the site of glucose inhibition). Hepatic glucose 6-phosphatase deficiency results in hypoinsulinaemic response to glucose [88], possibly as an adaptive response of islet GK to chronic hypoglycaemia.

The possible role of candidate genes in respect of insulin resistance has thus far been mainly confined to rare examples of insulin receptor gene mutations. Possible links with the main theme of this review have been alluded to in consideration of the likely regulatory role of the hexosamine biosynthetic pathway initiated by the GFAT reaction. Other topics of obvious interest include possible effects of events in utero (e.g. fetal nutrition) on gene expression in later life [64].

\section{References}

1. Burant CF, Sivitz WI, Fukomoto H et al. (1991) Mammalian glucose transporters: structure and molecular regulation. Recent Progr Horm Res 47: 349-387

2. Cahill GF Jr, Ashmore J, Earle AS, Zottu S (1958) Glucose penetration into liver. Am J Physiol 192: 491-496

3. Cahill GF Jr, Hastings AB, Ashmore J, Zottu S (1958) Studies on carbohydrate metabolism in liver slices. X.Factors in the regulation of pathways of glucose metabolism. J Biol Chem 230: 125135

4. DiPietro DL, Sharma C, Weinhouse S (1962) Studies on glucose phosphorylation in rat liver. Biochemistry 1: $455-462$

5. Viñuela E, Salas M, Sols A (1963) Glucokinase and hexokinase in liver in relation to glycogen synthesis J.Biol Chem 238 : PC1175-PC1177

6. Salas J, Salas M, Viñuela E, Sols A (1965) Glucokinase of rabbit liver. Purification and properties. J Biol Chem 240: 1014-1018

7. Grodsky GM, Batts AA, Bennett LL, Vcella C, McWilliams NB, Smith DF (1963) Effects of carbohydrates on secretion of insulin from isolated rat pancreas. Am J Physiol 205: 638-644

8. Coore HG, Randle PJ (1964) Regulation of insulin secretion studied with pieces of rabbit pancreas incubated in vitro. Biochem J 93: 66-78

9. Randle PJ (1964) Rate of release of insulin in vitro. Ciba Foundation Colloquia Endocrinol 17: 107-113

10. Coore HG, Randle PJ, Simon E, Kraicer PF, Shelesnyak MC (1963) Block of insulin secretion from the pancreas by D-mannoheptulose. Nature 197: 1264-1266

11. Coore HG, Randle PJ (1964) Inhibition of glucose phosphorylation by mannoheptulose. Biochem J 91: 56-59

12. Matschinsky FM, Ellerman (1968) Metabolism of glucose in the islets of Langerhans. J Biol Chem 243: 2730-2736

13. Randle PJ, Ashcroft SJH, (1969) Carbohydrate metabolism in pancreatic islets and the release of insulin. Biochem J 112: $1 \mathrm{P}-2 \mathrm{P}$

14. Ashcroft SJH, Randle PJ (1970) Enzymes of mouse pancreatic islets. Biochem J 119: 5-15

15. Meglasson MD, Burch PT, Berner DK, Najafi H, Matschinsky FM (1983) Chromatographic resolution and kinetic characterization of glucokinase from islets of Langerhans. Proc Natl Acad Sci USA 80: 85-89

16. Iynedjian PB, Mobius G, Seitz HJ, Wollheim CB, Renold AE (1986) Tissue specific expression of glucokinase: identification of the gene product in liver and pancreatic islets. Proc Natl Acad Sci USA 83: 1998-2001

17. Iynedjian PB, Pilot PR, Nouspikel Tet al. (1989) Differential expression and regulation of the glucokinase gene in liver and islets of Langerhans. Proc Natl Acad Sci USA 86: 7838-7842,

18. Jetton TL, Magnuson MA (1992) Heterogeneous expression of glucokinase among pancreatic beta cells. Proc Natl Acad Sci USA 89:2619-2623

19. Magnuson MA, Shelton KD (1989) An alternate promoter in the glucokinase gene is active in the pancreatic $\beta$-cell. J Biol Chem 264: $15936-1.5942$

20. Koranyi LI, Tanizawa Y, Welling CM, Rabin DU, Permutt MA (1992) Human islet glucokinase gene. Isolation and sequence analysis of full length cDNA. Diabetes 41: 807-811

21. Randle PJ, Ashcroft SJH, Gill JR (1968) Carbohydrate metabolism and release of hormones. In: Dickens F, Randle PJ, Whelan WJ (eds) Carbohydrate metabolism and its disorders, vol 1. Academic Press, London, pp 427-447

22. Landgraf R, Kotler-Brajtburg J, Matschinsky FM (1971) Kinetics of insulin release from the perfused rat pancreas caused by 
glucose, glucosamine and galactose. Proc Natl Acad Sci USA 68: $536-540$

23. Matschinsky FM, Ellerman JE, Krzanowski J, Kotler-Brajtburg J, Landgraf R, Fertel R (1971) The dual function of glucose in islets of Langerhans. J Biol Chem 246:1007-1011

24. Ashcroft SJH (1980) Glucoreceptor mechanisms and the control of insulin release and biosynthesis. Diabetologia 18: 5-15

25. Capito K, Hedeskov CJ (1976) Inosine-stimulated insulin release and metabolism of inosine in isolated mouse pancreatic islets. Biochem J 158: 335-340

26. Hellman B, Idahl L-A, Lernmark $\AA$, Sehlin J, Täljedal I-B (1974) The pancreatic $\beta$-cell recognition of insulin secretagogues. Comparison of glucose with glyceraldehyde and dihydroxyacetone. Arch Biochem Biophys 162: 448-457

27. Randle PJ, Hales CN (1972) Insulin release mechanisms. In: Handbook of physiology. Endocrinology, vol 1. American Physiological Society, Washington. pp 219-235

28. Ashcroft SJH, Bassett JM, Randle PJ (1972) Insulin secretion mechanisms and glucose metabolism in isolated islets. Diabetes [Suppl 2] 21:538-545

29. Williams IH, Ashcroft SJH (1978) N-acetylglucosamine and the substrate-site hypothesis for the control of insulin biosynthesis and secretion. FEBS Lett 87: 115-120

30. Ashcroft FM, Ashcroft SJH (1992) Mechanism of insulin secretion. In: Ashcroft FM, Ashcroft SJH (eds) Insulin: molecular biology to pathology. IRL Press at Oxford University Press, Oxford pp 97-150

31. Brown GC (1992) Control of respiration and ATP synthesis in mammalian mitochondria and cells. Biochem J 284: 1-13

32. Hellerström C (1967) Effects of carbohydrates on the oxygen consumption of isolated pancreatic islets of mice. Endocrinology $81: 105-112$

33. Waddell ID, Burchell A (1988) The microsomal glucose 6-phosphatase enzyme of pancreatic islets. Biochem J 255: 471-476

34. Täljedal I-B (1969) Presence, induction and possible role of glucose 6-phosphatase in mammalian pancreatic islets. Biochem J 114: 387-394

35. Johnson NH, Newgard CB, Milburn JL, Lodish HF, Thorens B (1990) The high $K_{m}$ glucose transporter of islets of Langerhans is functionally similar to the low affinity transporter of liver and has an identical primary sequence. J Biol Chem 265: 6548-6551

36. Thorens B, Flier JS, Lodish HF (1990) Differential regulation of two glucose transporters in rat liver by fasting and refeeding and by diabetes and insulin treatment. Diabetes 39:712-719

37. Nishi S, Stoffel M, Xiang K, Shows TB, Bell GI, Takeda J (1992) Human pancreatic beta-cell glucokinase: cDNA sequence and localization of the polymorphic gene to chromosome 7 , band $p$ 13. Diabetologia 35:743-747

38. Tanizawa Y, Koranyi LI, Welling CM, Permutt MA (1991) Human liver glucokinase gene: cloning and sequence determination of two alternately spliced cDNAs. Proc Natl Acad Sci USA 88: 7294-7297

39. Andreone TL, Printz RL, Pilkis SJ, Magnuson MA, Granner DK (1989) The amino acid sequence of rat liver glucokinase deduced from cloned cDNA. J Biol Chem 264: 363-369

40. Magnuson MA, Andreone TL, Printz RL, Koch S, Granner DK (1989) Rat glucokinase gene: structure and regulation by insulin. Proc Natl Acad Sci USA 86: 4838-4842

41. Stoffel M, Froguel Ph, Takeda J et al. (1992) Human glucokinase gene: isolation, characterization, and identification of two missense mutations linked to early non-insulin-dependent (type 2) diabetes mellitus. Proc Natl Acad Sci USA 89: 7698-7702

42. Walker DG, Rao S (1964) The role of glucokinase in the phosphorylation of glucose by rat liver. Biochem J 90:360-368

43. Ashmore J, Hastings AB, Nesbett FB (1954) The effect of diabetes and fasting on liver glucose 6-phosphatase. Proc Natl Acad Sci USA 40: 673-678

44. Iynedjian PB, Ucla C, Mach B (1987) Molecular cloning of glucokinase cDNA. Developmental and dietary regulation of glucokinase mRNA in rat liver. J Biol Chem 262: 6032-6038
45. Iynedjian PB, Gjinovici A, Renold AE (1988) Stimulation by insulin of glucokinase gene transcription in liver of diabetic rats. J Biol Chem 263: 740-744

46. Sibrowski W, Seitz HJ (1984) Rapid action of insulin and cyclic AMP in the regulation of functional mRNA coding in rat liver. $J$ Biol Chem 259: 343-346

47. Grey NJ, Goldring S, Kipnis DM (1970) Evidence for a glucoseinducible glucoreceptor for insulin secretion in the rat. Nobel Symposia 13: 155-168

48. Tiedge M, Lenzen S (1991) Glucokinase and glucose transporter gene expression in B-cells. Biochem J 279: 899-901

49. Malaisse WJ, Sener A, Levy J (1976) The stimulus-secretion colipling of glucose-induced insulin release. Fasting induced adaptation of key glycolytic enzymes. J Biol Chem 251:1731-1737

50. Sako Y, Grill VE (1990) 48-Hour lipid infusion in the rat time-dependently inhibits glucose-induced insulin secretion and $\beta$-cell oxidation through a process likely coupled to fatty acid oxidation. Endocrinology 127: 1580-1589

51. Dawson CM, Hales CN (1969) The inhibition of rat liver glucokinase by palmityl CoA. Biochim Biophys Acta 176: 657-659

52. Liang Y, Najafi H, Smith RF et al. (1992) Concordant glucose induction of glucokinase, glucose usage, and glucose-stimulated insulin release in pancreatic islets maintained in organ culture. Diabetes 41: 792-806

53. MacDonald MJ, Kaysen JH, Moran SM, Pomije CE (1991) Pyruvate dehydrogenase and pyruvate carboxylase. Sites of pretranslational regulation by glucose of glucose-induced release in pancreatic islets. J Biol Chem 266: 22392-22397

54. Van Schaftingen E, Vandercammen A (1989) Stimulation of glucose phosphorylation by fructose in isolated rat hepatocytes. Eur J Biochem 179: 173-177

55. Van Schaftingen E (1989) A protein from rat liver confers to glucokinase the property of being antagonistically regulated by fructose 6-phosphate and fructose 1-phosphate. Eur J Biochem 179: 179-184

56. Vandercammen A, Van Schaftingen E (1990) The mechanism by which rat liver glucokinase is inhibited by the regulatory protein. Eur J Biochem. 191: 483-489

57. Vandercammen A, Van Schaftingen E (1990) Competitive inhibition of liver glucokinase by its regulatory protein. Eur J Biochem 200: 545-551

58. Davies DR, Detheux M, Van Schaftingen E (1990) Fructose 1-phosphate and the regulation of glucokinase activity in isolated hepatocytes. Eur J Biochem 192: 283-289

59. Detheux M, Vandercammen A, Van Schaftingen E (1991) Effectors of the regulatory protein acting on liver glucokinase: a kinetic investigation. Eur J Biochem 200:553-561

60. Malaisse WJ, Malaisse-Lagae F, Davies DR, Vandercammen A, Van Schaftingen E (1990) Regulation of glucokinase by a fructose 1-phosphate-sensitive protein in pancreatic islets. Eur $\mathrm{J}$ Biochem 190: 539-545

61. Nuttall FQ, Gannon, MC, Burmeister LA, Lane, JT, Pyzdrowski KL (1992) The metabolic response to various doses of fructose in type-II diabetic subjects. Metabolism 41: $510-517$

62. Traxinger RR, Marshall S (1992) Insulin regulation of pyruvate kinase activity in isolated adipocytes. Crucial role of glucose and the hexosamine biosynthesis pathway in the expression of insulin action. J Biol Chem 267: 9718-9723

63. Marshall S, Garvey WT, Traxinger RR (1991) New insights into the metabolic regulation of insulin action and insulin resistance: role of glucose and amino acids. FASEB J 5:3031-3036

64. Hales CN, Barker DJP (1992) Type 2 (non-insulin-dependent) diabetes mellitus: the thrifty phenotype hypothesis. Diabetologia 35: 595-601

65. Perley MJ, Kipnis DM (1967) Plasma insulin responses to oral and intravenous glucose: studies in normal and diabetic subjects. J Clin Invest 46: 1954-1962

66. Himsworth HP (1936) Diabetes mellitus: its differentiation into insulin-sensitive and insensitive types. Lancet I: $127-130$

67. Shulman GI, Rothman DL, Jue T, Stein P, DeFronzo RA, Shulman RG (1990) Quantification of muscle glycogen synthesis in 
normal subjects and subjects with non-insulin-dependent diabetes by ${ }^{13} \mathrm{C}$ nuclear magnetic resonance. $\mathrm{N}$ Engl J Med 322 : 223-228

68. Groop LC, Bonadonna RC, Del Prato S et al. (1989) Glucose and free fatty acid metabolism in non-insulin dependent diabetes mellitus. Evidence for multiple sites of insulin resistance. J Clin Invest 84: 205-213

69. Robertson RP (1992) Defective insulin secretion in NIDDM: integral part of multiplier hypothesis. J Cell Biochem 48: 227-233

70. Grodsky GM, Bolaffi JL (1992) Desensitization of the insulinsecreting beta cell. J Cell Biochem 48:3-11

71. Matschinsky FM (1990) Glucokinase as glucose sensor and metabolic signal generator in pancreatic beta cells and hepatocytes. Diabetes 39: 647-652

72. Chiu KC, Province MA, Permutt MA (1992) Glucokinase gene is genetic marker for NIDDM in American Blacks. Diabetes 41 : 843-849

73. Chiu KC, Province MA, Dowse GK et al. (1992) A genetic marker at the glucokinase gene locus for type 2 (non-insulin-dependent) diabetes mellitus in Mauritian Creoles. Diabetologia 35: 632-638

74. Hattersley AT, Turner RC, Permutt MA et al. (1992) Linkage of type 2 diabetes to the glucokinase gene. Lancet 339: 1307-1310

75. Vionnet N, Stoffel M, Takeda J et al. (1992) Nonsense mutation in the glucokinase gene causes early-onset non-insulin dependent diabetes mellitus. Nature 356: 721-722

76. Froguel Ph, Vaxillaire M, Sun F et al. (1992) Close linkage of glucokinase locus on chromosome $7 p$ to early-onset non-insulin dependent diabetes mellitus. Nature 356: 162-164

77. Stoffel M, Patel P, Lo Y-MD et al. (1992) Characterisation of a missense glucokinase mutation in maturity-onset diabetes of the young (MODY) and mutation screening in late-onset diabetes. Nature Genetics 2: 153-156

78. Velho G, Froguel Ph, Clement K et al. (1992) Primary pancreatic beta-cell secretory defect caused by mutations in glucokinase gene in kindreds of maturity onset diabetes of the young. Lancet 340: 444-448

79. Page R, Hattersley A, Turner R (1992) Beta-cell secretory defect caused by mutation in glucokinase gene. Lancet 340:1162(Letter)
80. Velho G, Clement K, Pueyo ME, Froguel Ph (1992) Beta-cell secretory defect caused by mutation in glucokinase gene. Lancet 340:1162-1163 (Letter)

81. Vionnet M, Stoffel M, Takeda J et al. (1992) Mutations in glucokinase gene cause early onset type 2 diabetes. Diabetologia 35 [Suppl 1]: A62 (Abstract)

82. Froguel Ph, Vionnet N, Stoffel M et al. (1992) Different phenotypic expression by three mutant alleles of glucokinase gene in MODY. Diabetologia 35 [Suppl]: A63 (Abstract)

83. Bell GI, Xiang K-S, Newman MV et al. (1991) The gene for noninsulin dependent diabetes mellitus (maturity onset diabetes of the young subtype) is linked to DNA polymorphism on human chromosome 20 q. Proc Natl Acad Sci USA 88: 1484-1488

84. Permutt MA, Chiu KC, Tanizawa Y (1992) Glucokinase and NIDDM. A candidate gene that paid off. Diabetes 41: 1367-1372

85. Matsutani A, Koranyi L, Cox N, Permutt MA (1990) Polymorphisms of GLUT 2 and GLUT 4 genes. Use in evaluation of genetic susceptibility to NIDDM in blacks. Diabetes 39: 1534-1542

86. Patel P, Lo Y-MD, Hattersley A et al. (1992) Linkage analysis of maturity-onset diabetes of the young with microsatellite polymorphisms. No linkage to ADA or Glut 2 genes in two families. Diabetes 41: 962-967

87. Alcolado JC, Baroni MG, Li SR (1991) Association between a restriction fragment length polymorphism at the liver/islet cell (GLUT 2) glucose transporter and familial type 2 (non-insulindependent) diabetes mellitus. Diabetologia 34: 734-736

88. Lockwood DH, Merimee TJ, Edgar PJ et al. (1969) Insulin secretion in type I glycogen storage disease. Diabetes 18:755-758

89. Gould GW, Thomas HM, Jess TJ, Bell GI (1991) Expression of human glucose transporters in Xenopus oocytes: kinetic characterization and substrate specificities of the erythrocyte liver and brain isoforms. Biochemistry 30 : 5139-5145

Prof. P.J.Randle

Nuffield Department of Clinical Biochemistry

John Radcliffe Hospital

Oxford OX39DU

UK 